\title{
Academic freedom as a source of rights' violations: a European perspective
}

\author{
Monika Stachowiak-Kudła ${ }^{1}$
}

Accepted: 23 April 2021 / Published online: 8 May 2021

(C) The Author(s) 2021

\begin{abstract}
The application of academic freedom may lead to a violation of individual rights, such as the right to respect private life or institutional rights such as university autonomy, or the right of the religious community to self-determination. These collisions between rights are resolved by constitutional courts either according to the proportionality test or by balancing the rights. This paper investigates cases from Czechia, Germany, Italy, Poland, and Spain, where academic freedom collided with other constitutional rights, in order to determine methods for resolving these types of conflicts. This analysis demonstrates the way in which proportionality allows the construction of the content of academic freedom. It also shows the reasons why academic freedom could become a weak right and why sometimes it is a strong right.
\end{abstract}

Keywords Academic freedom $\cdot$ Principle of proportionality $\cdot$ Weak right $\cdot$ Freedom of scientific research $\cdot$ Freedom of teaching

\section{Introduction}

Academic freedom has many definitions and is understood differently (Altbach 2001). In the 1997 Recommendation Concerning the Status of Higher-Education Teaching Personnel, signed by all countries included in this study, academic freedom is equated with "the right, without constriction by prescribed doctrine, to freedom of teaching and discussion, freedom in carrying out research and disseminating and publishing the results thereof, freedom to express freely their opinion about the institution or system in which they work, freedom from institutional censorship and freedom to participate in professional or representative academic bodies" (UNESCO, 11 November 1997). Moreover, some lawyers link the protection of intellectual property with the development of academic freedom (e.g., Davies 2015, 991).

Monika Stachowiak-Kudła mstachowiak@poczta.fm

1 Faculty of Administration and Social Sciences, Warsaw University of Technology, street Plac Politechniki 1, 00-661 Warsaw, Poland 
Academic freedom is a defensive right, and therefore one that protects scientific and teaching activities against the interference of the state and other authorities, including university and faculty authorities. This important aspect of academic freedom is often taken up in the literature (Enders et al. 2013, 23) particularly in the context of knowledge creation (Karran 2009b, 191; Rittberger and Richardson 2019, 324; Beiter et al., 2016, 272). Academic freedom serves to identify the truth. It is also seen as an act "in the best interests of others, the future of others and other futures" (Gibbs 2016, 184, see also Rena and Li 2013, 511; Thorens 2006, 87-110).

According to Alexy's theory $(2000,2002)$, fundamental rights and freedoms, which also include academic freedom, are also principles and may collide with other rights. The application of academic freedom may lead to a violation of other individual or institutional rights. The collision between two or more rights is settled by constitutional courts and international tribunals by applying the principle of proportionality (Rivers 2014, 413; Jackson 2015, 3094-3196; Brems and Lavrysen 2015). In the traditional approach, the principle of proportionality is used to determine whether a statutory limitation imposed on a fundamental right is justifiable (Feteris 2008).

In recent literature, there is a growing interest in the merits and detriments of the principle of proportionality (Ramshaw 2019; Stacey 2019; Alexy 2020; Poscher 2020). The application of proportionality in the area of academic freedom is a less discussed issue, yet of vital importance to the ongoing debate for two reasons. Firstly, academic freedom can collide not only with other individual rights but also with institutional rights. This aspect has not been sufficiently analyzed in literature. Secondly, in some countries (France, Hungary, Italy, Poland, and Spain), academic freedom does not have a legal definition and in the event of a dispute, courts have to determine the essence of this right. Proportionality promotes a dialog between the judge and lawmaker thereby making the content of academic freedom concrete. The main advantage of proportionality is the help it offers in defining the minimum core content of academic freedom.

This paper strives to clarify how academic freedom is understood in the jurisprudence of constitutional courts. The original database includes all 97 judicial decisions from 9 European countries fulfilling two criteria: they have constitutional courts and they provide constitutional regulations protecting academic freedom. ${ }^{1}$ The data was obtained from the Constitutional Courts' databases of case law. The collisions of principles are rare. The collision with academic freedom occurred in only five cases from five countries: Czechia (2017), Germany (2008), Italy (2017), Poland (2008), and Spain (1996).

This article also strives to determine how constitutional courts resolve conflicts of rights by using the principle of proportionality to justify limitations of academic freedom. It is researched by checking how the courts consider the three elements of the proportionality principle sensu largo (suitability, necessity, and proportionality in narrow sense) in the five cases where academic freedom collided with other constitutional rights. Based on this analysis, the paper demonstrates the way in which proportionality helps to define the content of academic freedom. It also reveals the reasons why the courts found academic freedom turns out to be a weak right and why sometimes it is a strong right.

\footnotetext{
${ }^{1}$ The decisions were selected from online legal information systems. The researched period is not equal for each country: Belgium since 1985, Czechia since 1993, France since 1958, Germany since 1973, Hungary since 1990, Italy since 1956, Poland since 1997, Portugal since 1983, and Spain since 1980.
} 
The article is structured as follows. After introducing the key problem, the second section delineates the legal content of academic freedom. The third section justifies the existence of the principle of proportionality. The fourth part offers insight into the decisions of constitutional courts that seem to redefine concepts of academic freedom. The final section briefly concludes the findings of the paper.

\section{Academic freedom}

Academic freedom is a right protected by the Article 13 of the Charter of Fundamental Rights of the European Union (2000/C 364/01). In the texts of the constitutions of Germany (Article 5(3)), Hungary (Article X(1)), Italy (Article 33), Poland (Article 73), and Portugal (Article 42 and 43), academic freedom appears in the form of freedom of scientific research and freedom of teaching (see also: Karran et al., 2017; Barendt 2010). The constitutions of Spain (Articles 20(1c) and 27(1)), Belgium (Article 24(1)), and France ${ }^{2}$ explicitly guarantee the freedom of teaching. The charter of fundamental rights and freedoms of Czechia explicitly guarantees only the freedom of scientific research (Article 15(2)).

The lack of one of the rights constituting academic freedom in the constitution does not necessarily mean that it is not guaranteed. The constitutional court may derive them from another right (Stachowiak-Kudła 2020, 25). The Belgian Constitutional Court (Arrêt $n^{\circ} 167 /$ $2005 \mathrm{du} 23$ novembre 2005) indicates that academic freedom stems from the freedom of expression guaranteed by the Article 19 of the Belgian Constitution and Article 10 of the European Convention on Human Rights and from freedom of teaching.

Only some of the surveyed countries adopted a legal definition of the rights constituting academic freedom. The legal definition of the freedom of teaching can be found in Belgian, Czech, and German laws, whereas the legal definition of the freedom of scientific research can be found in German and Portuguese laws (see Table 1, columns A and B).

In Belgium, the Decree of 31 March 2004 defining higher education, promoting its integration into the European space of higher education and refinancing the universities (Article 67) explains that freedom of teaching is the choice of teaching methods, scientific and technical contents, evaluation, and the various activities carried out in order to achieve the particular objectives of this teaching within the study program. In Czechia, the Act of April 22, 1998 on higher education institutions and on amendments and supplements of other acts (Article 4(b)) explains that freedom of teaching is guaranteed "in particular with regard to openness to different scientific and scholarly views, scientific and research methods and artistic movements." In Germany, the Framework law on higher education from January 19th, 1999 (Article 4) states that the freedom of research "shall in particular include posing questions, applying methodological principles, as well as evaluating and sharing research results." The freedom of teaching shall in particular include the teaching of courses, the creation of the courses' content, the methods of instruction, and the right to express artistic views and academic opinions. The relevant higher education bodies can make decisions only in regard to the organizational aspects of research, support, and coordination of a research project, or to define the main research focus, in addition to the organizational aspects of setting

\footnotetext{
${ }^{2}$ Freedom of teaching was defined as one of the basic principles of the French Republic in art. 91 Loi du 31 mars 1931 portant fixation du budget général de l'exercice 1931-1932. Then it was recognized in the introduction of the Constitution of October 27, 1946, and indirectly in the introduction of the Constitution of October 4, 1958.
} 
Table 1 Academic freedom in legal acts and jurisdiction

\begin{tabular}{llllll}
\hline & A & B & C & D & E \\
\hline Belgium & Yes & No & Yes & Yes & Yes \\
Czechia & Yes & No & Yes & Yes & Yes \\
Germany & Yes & Yes & Yes & Yes & Yes \\
France & No & No & Yes & No & No \\
Hungary & No & No & Yes & No & No \\
Italy & No & No & Yes & Yes & Yes \\
Poland & No & No & Yes & Yes & Yes \\
Portugal & No & Yes & Yes & Yes & Yes \\
Spain & No & No & Yes & & \\
\hline
\end{tabular}

Notes:

A - countries which have a legal definition of freedom of teaching;

B - countries which have a legal definition of freedom of scientific research;

$\mathrm{C}$ - the constitutional court indicated that academic freedom protects the individual from unjustified interference from public authority;

D - the constitutional court underlined the special relationship between the academic freedom and university autonomy;

E - the constitutional court stated that the academic freedom may be limited in order to protect the rights and freedoms of other people;

Source: Own survey of acts regulating higher education and jurisdiction the constitutional courts in the selected EU countries. Legal status revised at the beginning of 2019

up and maintaining the learning process and academic examinations. The Portuguese Constitution (Article 42(2) provides that the freedom of scientific research includes the right to create, produce, and distribute scientific works, and guarantees statutory copyright protection. In France, Italy, Poland, and Spain, the freedom of scientific research and the freedom of teaching are guaranteed in an Act; however, the essence of these freedoms has not been explained. ${ }^{3}$ In Hungary, the Act on National Higher Education does not include an academic freedom guarantee at all.

In those countries where there is no legal definition of academic freedom, the content of this right in the event of a dispute is determined by the court. The Constitutional Court of Poland (Wyrok z dnia 12 kwietnia 2012 r., sygn. akt. K 30/10) interpreted the essence of freedom of scientific research as the freedom to choose subjects for scientific research, freedom to choose methodology, and freedom to publish the results. In Poland, "the freedom to access all information that may be needed for the research" is also an element of the freedom of scientific research. The Constitutional Court of Hungary (34/1994. (VI. 24.) AB határozat) stated that the freedom of scientific research includes the right to conduct scientific research and to disseminate scientific truth and knowledge. As for the essence of freedom to teach, the Constitutional Court of Poland (Wyrok z dnia 12 kwietnia 2012 r., sygn. akt. K 30/10) said that it is the freedom of systematic transfer of knowledge to other people. In turn, the Constitutional Court of Spain stated that freedom of teaching is related to "the right to freely disseminate the thoughts, ideas and opinions of teachers while performing their functions" (STC 5/1981, de 13 febrero). The essence of academic freedom has been defined by the

\footnotetext{
${ }^{3}$ France: art L151.1, Code de l'éducation. Italy: Art 1(1), Legge 30 dicembre 2010, n. 240, Norme in materia di organizzazione delle università, di personale accademico e reclutamento, nonce delega al Governo per incentivare la qualità e l'efficienza del sistema universitario. Poland: Art 3, Act of 3 July 2018. The Law on Higher Education and Science. Spain: Art 39(2), Ley Orgánica 6/2001, de 21 de diciembre, de Universidades.
} 
Federal Constitutional Court of Germany (Beschluss vom 29. Mai 1973 - 1 BvR 424/71, 1 BvR 325/72), stating that it is the right to represent one's subject in research and teaching. The Constitutional Court of Spain (STC 179/1996, 12 de noviembre) said the same.

The constitutional courts of individual European countries perceive the subject of protection, as well as permitted and unacceptable restrictions resulting from the scope of protection of academic freedom, in a similar way. This is despite the fact judges of these courts decide in the complex social and institutional environment of their country. A thorough analysis of the jurisprudence of these courts allows us to identify the three basic aspects of academic freedom indicated by constitutional courts.

First, academic freedom is a defensive right, which protects scholarly activities against state interference and provides individual scholars with an absolutely protected autonomous space (Table 1, column C). Defensive rights are a prohibition against destruction. Alexy indicates that "When there is a prohibition on destroying or adversely affecting something, then every act that represents or brings about destruction or an adverse effect is prohibited" (Alexy 2015, 5). The Federal Constitutional Court of Germany states that the essence of the freedom of research is the lack of state interference in conducting research and the process of publishing of the results (Beschluss vom 29. Mai 1973 - 1 BvR 424/71, 1 BvR 325/72). The Constitutional Court of Czechia (13. záŕí 2017, III.ÚS 3393/15) has also spoken against state interference in the contents and methods of scientific activity. The Constitutional Court of Poland (Wyrok z dnia 7 lutego 2006 r., sygn. akt SK 45/04) similarly states that academic freedom "protect the individual and other right entities from ungrounded state interference in the subject and methods of scientific research and in the content and methods of teaching." Similar reasoning was proposed by the Constitutional Court of Spain (STC 26/1987, de 27 de febrero).

The Constitutional Court in Italy (Sentenza n. 143 del 6 luglio 1972) states that the freedom of teaching "does not tolerate political interference or even interference irrelevant to the technical and scientific foundations of teaching in the higher education institutions." The Constitutional Court in France (Décision n ${ }^{\circ} 93-322$ DC du 28 juillet 1993) pointed out that the implementation of teaching and research functions require guaranteeing the free expression and independence of academic teachers and researchers. At the same time, it is also pointed out that the protection concerns not only interference from the government but also from the university or faculty authorities. This aspect was pointed out by the Constitutional Court in both Belgium (Arrêt n ${ }^{\circ}$ 167/2005 du 23 novembre 2005) and Germany (Beschluss vom 29. Mai 1973 - 1 BvR 424/71, 1 BvR 325/72).

The character of academic freedom as a defensive right can sometimes be derived from the constitution. The Portuguese Constitution (Article 42(2)) states that: "The state may not program education and culture in accordance with any philosophical, aesthetic, political, ideological or religious directives." The Hungarian Constitution (Article 10(2)) similarly states that: "The State shall have no right to decide on questions of scientific truth; only scientists shall have the right to evaluate scientific research."

Second, the constitutional courts underline the special relationship between academic freedom and university autonomy (column D). The Constitutional Court of Spain states that the purpose of the university's autonomy is the protection of academic freedom (STC 26/1987, de 27 de febrero). The Constitutional Court of Poland (Wyrok z 8 listopada 2000 r., sygn. SK $18 / 99$ ) states, that "the autonomy of higher education aims to create conditions for these institutions to optimally implement their tasks in the field of research and teaching." In Germany, university autonomy is not guaranteed under the Basic Law although the Federal Constitutional Court (Beschluss vom 20. Juli 2010 - 1 BvR 748/06) country has also 
established that the state has the duty to support universities and to ensure suitable organizational measures fostering academic freedom. The Constitutional Courts in Italy (Sentenza n. 1017 del 26 ottobre 1988) and Czechia (13. Března 2008, Pl.ÚS 25/07) also draw attention to this special relationship between academic freedom and the autonomy of the universities.

Third, the constitutional courts agree that academic freedom may be limited in order to protect the rights and freedoms of other people ${ }^{4}$ (column E). In some legal systems, the limits of freedom and rights have already been regulated in the constitution. ${ }^{5}$ Limitation clauses specify the substantive content and the purpose of the limiting act by setting the rightful scope within which a right can be limited (Ali Nasir 2018; see also: Kumm 2007; Stacey 2019). This third aspect is particularly important to the paper's considerations because they list the circumstances when a law may be restricted and constitute the starting point for the proportionality test.

It is also worth pointing out that academic freedom should not be equated with the university's right to autonomy. Primarily because the subject (holder) of these two rights is someone else. The subject of the university's right to autonomy is the university's constitutive and executive bodies. In practice, this right is implemented by the university authorities, not by a single researcher or academic teacher. However, it may happen that in a country where the constitution does not guarantee universities' autonomy, the constitutional court will derive this right from freedom of teaching. For instance, this is the case in Germany (Beschluss vom 28. Oktober 2008 - 1 BvR 462/06). When the courts decide the conflict between academic freedom and university autonomy, the latter is a distinct right, not another aspect of academic freedom.

\section{The principle of proportionality and the collision of principles}

The use of principles (and therefore also academic freedom) is subordinated into three theses: the Optimization Thesis, the right of collision, and the right of balance. The Optimization Thesis claims that principles are optimization requirements, which means "requiring that something be realized to the greatest extent possible, given the factual and legal possibilities at hand" (Alexy 2002, 47-48). Sometimes, respecting or applying academic freedom may lead to a violation of some other right. For Alexy $(2002,185)$, collision of principles enforces a situation which requires balancing of each of the principles by determining whether the importance of the pursued aim justifies the seriousness of the infringement on the other right. The proportionality is therefore a tool for defending rights against limitations (Contiades and Fotiadou 2012, 665). Alongside the defensive aspect of proportionality, we also have the creative aspect. In this regard, proportionality is a tool for forming the content of the right (Cohen-Eliya and Porat 2010, 263).

The principle of proportionality defines the steps followed by a judge in solving collision of principles. These steps concern suitability, necessity, and proportionality in its narrow sense.

\footnotetext{
${ }^{4}$ Belgium: 44/2005 du 23 février 2005, 167/2005 du 23 novembre 2005, 2/2006 du 11 janvier 2006, 53/2016 du 21 avril 2016; Czechia: 13. záŕí 2017, III.ÚS 3393/15; Germany: Beschluss vom: 1 März 1978 - 1 BvR 333/75; 26. Oktober 2004 - 1 BvR 911/00; 28. Oktober 2008 - 1 BvR 462/06; 03. September 2014 - 1 BvR 1195/14. Italy: sentenza n. 383 del 23 novembre 1998. Poland: wyrok z dnia 25 listopada 2008 r., sygn. akt K 5/08. Spain: STC 5/1981, de 13 febrero; AUTO 457/1989, de 18 de septiembre.

${ }^{5}$ For example: Art 4, Charter of Fundamental Rights and Basic Freedoms of Czechia; Art 31(3), Constitution of Poland.
} 
The principle of suitability means that interference with one principle must contribute to the realization of the other. In turn, the principle of necessity requires that there be no other less restrictive means to achieve the same result. The principle of proportionality in the narrower sense is expressed in the following regularity: "[t]he greater the degree of non-satisfaction of, or detriment to, one principle, the greater must be the importance of satisfying the other" (Alexy 2002, 102). Some constitutional courts (for example, Spanish and Belgian) have developed specific elements of the proportionality test (Popelier and van de Heyning 2013, 236).

There is no consensus in the literature on whether the principle of proportionality sensu largo is the proper procedure for solving the collision of principles (Harbo 2010; Möller 2012). One of the main criticisms directed against proportionality theories has been the incommensurability objection. This is a complaint formulated primarily by Rao $(2008,238)$, Tsakyrakis $(2009,489)$, and Webber $(2009,101-110)$. It essentially means that one should not compare the ways in which rights and public interests are affected in judicial review cases using a common measure. In turn, Khosla (2010, 298), Da Silva (2011, 273-301), Barak (2012, 458), Klatt and Meister (2012, 687-708), and Urbina (2005), 605 deny this by claiming that incommensurability is not an obstacle for rights' cases to be decided reasonably. The second objection concerned the rationality of balancing of principles. It was formulated by Habermas (1996, 258-259; see also: Novak 2010, 104), who pointed out that because there are no rational standards for balancing, the courts, when balancing rights against politics, can decide arbitrarily. The critics of the proportionality principle point to an alternative method of resolving conflicts of rights, namely Dworkin's rights as trumps model (Weinrib 2017, 341; La Torre 2018, 187). The third objection concerned the dichotomy of principles and rules. It was formulated by Poscher $(2020,148)$.

Observing the practice of applying proportionality by the constitutional courts of individual states, we can see that two models have developed in this area. The first "comes within a model of constitutionalism that confers normative priority to constitutional rights over competing norms, values and interests," while the second conception comes within a model that confers no normative priority to rights, striving for their optimization (Tremblay 2014). The second model is represented, for example, by the Italian Constitutional Court (Sentenza n. 85 del 9 aprile 2013), which concluded that "all fundamental rights protected by the Constitution are interrelated and therefore none of them can be said to be more important."

Proportionality in the aspect of academic freedom has come under scrutiny only recently. For example, Earle and Cava (1997) and Matejkovic and Redle (2006) showed (by analyzing the jurisprudence of the Supreme Court of the USA) that the protections of academic freedom come into conflict with protections granted to students under Title IX against sexual discrimination and harassment. Matejkovic and Redle observed that if any discussion of a sexual nature is specifically and legitimately related to a valid pedagogical end, academic freedom claims must prevail. However, when no legitimate pedagogical end is involved then the sexual harassment protections must prevail. Mimler $(2015,129)$ compared the relationship between the right to property of the patent holder and the freedom of scientific research in UK and Germany. He analyzed, among others, the case of the German Federal High Court, where patent protection is not unlimited and the interest of the patent holder is balanced with the public interest by taking into account "the principle of freedom of research." Starck (2006) analyzed the potential limitation set on the freedom of scientific research in Germany, which could result from the protection of the right to privacy, environmental protection, protection of life and 
health, and human dignity. He also analyzed the Federal Constitutional Court of Germany's judgment from 1978 (Beschluss vom 1 März 1978 - 1 BvR 333/75), in which, the court considered freedom of scientific research as a weaker right.

\section{Academic freedom and the violation of other rights: national case studies}

Disputes in which the constitutional court resolved the issue of violation of academic freedom are rare. In the examined countries, over the last several decades, 97 decisions of constitutional courts refer to freedom of scientific research or freedom of teaching. However, only 22 cases relate to the direct violation of these freedoms. Most often, academic freedom is cited in the background of a dispute about another right. In 35 cases, the other right was university autonomy. In these matters, the constitutional courts cite academic freedom to indicate that the university autonomy is the protection of this freedom. I will present below five decisions which resolve the conflict between academic freedom and the other rights. These cases were selected because they met two criteria simultaneously: they contained one of the following phrases "proportionality," "collision," or "balancing" and concerned collisions of principles, one of which was academic freedom.

\section{The Czech case}

In 2017, the Constitutional Court of Czechia (13. záŕi 2017, III.ÚS 3393/15) dealt with the collision of freedom of scientific research (Article 15(2) of Charter of Fundamental Rights and Freedoms) with the rights to privacy and personality (Article 10 (1 and 3). The case was brought against the background of the following facts: an historian in his scientific publication compared one of the persons described in his book to a Nazi leader and called her a traitor to Czechoslovakia. The daughter of the person brought the case to the Court pointing to the violation of the rights to honor and dignity. The historian, after losing the case in the appeal, lodged a complaint with the Constitutional Court of Czechia, pointing out an infringement on her constitutional rights arising from the Charter of Fundamental Rights and Freedoms that were violated, in particular, freedom of expression (Article 17), freedom of scientific research, the right to protection of personality (Article 10 (1 and 3), and the right to a court (Article $36(1)$.

In this decision, steps taken by the Court to resolve the conflict of principles are not as obvious as in the Polish and Italian cases. First, the Court recalled the principles according to which the court, as well as the European Court of Human Rights, solves the conflict between freedom of expression and other constitutional rights. It reminded, that:

[t]he following statements must always be taken into account: their nature (whether it is a factual claim or a value/judgmental statement); content (eg. 'political' or 'commercial' speech); the form (especially to what extent the subject is expressive or even vulgar); the position of the person being criticized (a public person, a known person or a politically active one); whether the statement (criticism) affects the private or public sphere of a person; the behavior of the person being criticized (for example, criticism 'provoked' itself); critics of the position (journalist, ordinary citizen, politician); the circumstances in 
which the statement was made (the extent of the specific information and the contextual situation of the author).

Second, the Constitutional Court analyzed whether the means used to achieve the goal were appropriate. The Court argued that:

in the case at hand it is significant that the contested statements represent the results of the complainant's scientific research (as a historian and 'professional') and her assessment (judgment), expressing her opinion as an author and her attitude toward the facts based on her own (subjective) criteria' and 'criticism expressed in value judgments must be appropriate and justified, meaning the facts that served as the basis for the criticism must be proven in the degree corresponding to the resulting value judgment and the critic must provide the proof herself.

According to the Court, the acceptable degree of public criticism must not break out of the confines of the recognized rules of decency. In the opposite case, it goes beyond constitutional protection.

Thirdly, the court pointed out that the freedom of scientific research has certain limitations and ends where it collides with other constitutional rights. Ethical standards also act as a natural corrective to freedom of scientific research. In this case, the Court found that the complainant violated the freedom of scientific research by comparing one of the people described in his book to a Nazi leader and a traitor to Czechoslovakia, exceeding the acceptable level of criticism.

In this judgment, one of the judges formulated a dissenting opinion, pointing to two important issues. First, the judge claimed that the freedom of expression can be limited only by law, and only when necessary in a democratic state for the protection of public order. Second, this judge was convinced that the complainant did not exceed the limits of the protection of the freedom of scientific research. I agree with that judge. Academic freedom serves to identify the truth. If it is true that the person described by the historian was in fact a criminal and betrayed own country then it should not matter to this historian that this person was not convicted of these acts by a court. Especially if he was not convicted, because he died before the court verdict.

The Czech example also shows that in legal practice, often large parts of the argumentation remain implicit and it is not clear which arguments affect the decision. Similar conclusions were drawn earlier by Feteris $(2008,493)$, who investigated the collisions between other freedoms.

\section{The German case}

In 2008, the Federal Constitutional Court of Germany (Beschluss vom 28. Oktober 2008 - 1 BvR 462/06) was reconciling the tension between freedoms of teaching (Article 5.3 of the Basic Law) on the one hand, and the right of the religious community to self-determination (Article 140 of the Basic Law in conjunction with Article 137.3 of the Weimar Constitution) on the other.

The subject of the dispute in this case was the decision of the authorities of one of the faculties of Göttingen University assigning the applicant an elective course of "History and Literature of the Early Christianity" in place of the previously conducted obligatory 
subject "New Testament." This decision of the Faculty was caused by the fact that the professor publicly no longer maintained the beliefs of the church. The Court found that the allocation of the complainant to another subject encroaches on the complainant's fundamental right under Article 5.3 sentence 1 of the Basic Law $(1,2)$, but this encroachment was justified with regard to the right of the religious community to selfdetermination.

The Court examined the limitations of fundamental rights using the four-step test (Grimm 2015, 19). In the first step, it defined the purpose of the statutory limitation of the fundamental right and examined whether this purpose is compatible with the Basic Law. It concluded that the freedom of teaching may be restricted by the other constitutional rights. The Court found two reasons on the basis of which limitation of the freedom of teaching may be justified. The first one concerns the right of the church to manage its affairs. The second one concerns the need to enable institutions of higher education to fulfill their obligations in teaching and research. The Court recognized that if the state decides to teach theology at its universities as the scholarly study of faith related to a particular religious denomination, it must take account of the rights of the church to administer its own affairs. For this reason, the Court recognized that the position of the lecturer at a theological faculty can be related to a particular religious denomination.

The next two steps deal with the relation between means and ends. The Court clearly indicated that in these circumstances, the means were appropriate and necessary to achieve the ends pursued. The complainant kept his position as a university lecturer and he was allocated a subject "History and Literature of the Early Christianity" that is largely similar to his original subject "New Testament." Nor do the consequences of the transfer for the complainant's position in teaching and examinations make the measure unreasonable. The Court stated that " $[\mathrm{t}]$ he failure to consider the new subject of the complainant in the examination and study regulations of the Göttingen Theological Faculty does not negatively affect the complainant's freedom of teaching," because the consequences of introducing this solution go beyond the mere difficulties of finding interested students. The Court found that unlike the exclusion from the theological training, the exclusion from examination-relevant-courses of studies does not conflict with constitutional interests. Admittedly, the dissolution of the complainant from the Christian faith gives a reason to exclude him from the training of young theologians, by also marking this in the list of lectures. In any case, it is at the discretion of the church to cease accepting him as an examiner for the ecclesiastical examinations. The Court also agreed with the Federal Administrative Court's decision that the impairment of the freedom of teaching was already mitigated by the fact that the complainant retained his right to advance in career and award academic titles. Afterwards, the Court found that "[n]o more lenient means was evident that would have had less impact on the freedom of scholarship and similarly promoted the legitimate purpose than depriving the complainant of a subject related to a particular religious denomination and allocating him a subject that was not related to a particular religious denomination within the Theology Faculty."

In the last step, the Court found that the advantage of pursuing the aim by the means in question outweighs the costs. The Court pointed out that the lecturers of a theology faculty no longer publicly upholding the beliefs of the church would result in a lack of adequate conditions for the training of the clergy of the church and teachers of religious education. 


\section{The Italian case}

In 2017, the Constitutional Court of Italy (Sentenza n. 42 del 21 febbraio 2017) ruled on the conflict of universities' right to autonomy (Article 33(6) of the Constitution) with three other principles: the principle of equality, the primacy of the Italian language, and freedom of teaching (Articles 3, 33(1) and 34 of the Constitution).

Academic Senate of the Polytechnic in Milan, under its right to autonomy, adopted a resolution according to which Master and PhD degree courses from 2014 onwards had to be conducted in English-only. This resolution was a consequence of the implementation of the Article 2 of Law 240/2010 concerning the organization of universities. The contested Article stated that the "reinforcement of internationalization also through greater mobility of the faculty and students, integrated study programmes, inter-university cooperation schemes for study and research activities, and the activation [...] of teaching, courses of study and forms of selection held in a foreign language." Academic Senate of the Polytechnic in Milan limited the principle of equality, the primacy of the Italian language, and freedom of teaching in order to internationalize the teaching process. The Court deemed that the purpose of limiting the rights is justified; however, the means used to achieve the goal were not adequate. In addition, the Court found the applied means were not the least onerous.

The internationalization of universities must take place without prejudice to the constitutional principle of the primacy of the Italian language, equal rights in the access to university education, and freedom of teaching. The Court considered that the legitimate aims of internationalization within the Italian universities must not marginalize the Italian language to a subordinate role. The Court noted that if the universities had the opportunity to prepare an offer of general education which covers entire subjects of study conducted only in a language other than Italian, then it would impose an additional requirement of knowing another language on the candidates wishing to study that subject. The Court also drew attention to the economic factor of such an additional requirement. Additionally, the Court pointed out that conducting education exclusively in another language could be detrimental to the freedom of teaching, because it would affect the way students communicate with their academic teacher, obliging the teacher to know the language, and discriminate against those who do not know the language. The Court clearly indicated that the used means could be replaced by other means that better reconcile the rights. The Court offered a solution that is consistent with the Italian Constitution stating that it is legitimate to institute courses of study in English, provided that the same courses are also offered in Italian.

In this judgment, the Court clearly found teaching exclusively in English to be disproportionate. The court's proportionality analysis was very thorough and the court proposed a less restrictive solution.

\section{The Polish case}

In 2008, the Constitutional Court of Poland (Wyrok z dnia 25 listopada 2008 r., sygn. akt K $5 / 08$ ) resolved the conflict between the right to information (Article 54 (1) of the Polish Constitution) and the freedom of scientific research (Article 73) on the one hand, and protection of the right to private life (Article 47) and information autonomy (Article 51(14)) on the other. The Commissioner for Human Rights challenged two passages of the Act of June 29th, 2007, amending the act on the Institute of National Remembrance-Commission for the Prosecution of Crimes against the Polish Nation (Article 36) regarding the condition of 
access to archives: for the purpose of scientific research - a recommendation of a researcher if the person declaring a research goal is not a researcher himself and for the purpose of a press publication with the authorization of the editorial office or publisher. In his opinion, the provisions disproportionately limited academic freedom by requiring a recommendation.

The Court argued that the requirement to recommend a person applying for access to the archives of the Institute of National Remembrance by a "researcher" is to guarantee constitutional protection (information autonomy) of those who publish as well as those whom the publication concerns. It grants them the opportunity to present their own point of view, rectify, or remove inaccuracies.

The freedom of scientific research and the right to information were therefore limited by the Parliament in order to protect the rights of others. The purpose of restricting the right is therefore justified. The Court stated that the guarantee mechanism provided by the Act is the only protection for people whom the archives concern. The Court pointed to one more argument: the purpose of access to archives can be more easily verified. The Court did not get involved in reviewing the means which could be replaced by other means restricting the right to a lesser extent. Finally, the Court stated that the benefit of protecting the privacy of the people whom the archives concern by introducing the verification procedure described above outweighs the cost of limiting the freedom of scientific research.

The Polish case is important because in Poland, academic freedom is available to everyone and does not have to be associated with an academic community. The Constitution clearly indicates (Article 73) that everyone is entitled to the freedom of scientific research and the freedom of teaching. Poland is an exception in this regard. In other large European countries, for example, Italy (Constitutional Court of Italy, Sentenza n. 42/2017 del 21 febbraio 2017) and Spain (Constitutional Court of Spain: STC 179/1996, de 12 de noviembre de 1996 and STC 5/1981, de 13 de febrero de 1981), the constitutional courts indicate only the academic researchers and teachers as holders of the freedom of scientific research and the freedom of teaching.

\section{The Spanish case}

In 1996, the Constitutional Court of Spain (STC 179/1996, 12 de noviembre) resolved the conflict between academic freedom and the autonomy of Universities guaranteed respectively in Articles 20(1c) and 27(10) of the Spanish Constitution. ${ }^{6}$ The case was brought against the background of the following facts: The Technical University of Madrid filed a constitutional motion (amparo) for relief against the judgment of the Spanish National Court-Chamber for Contentious-Administrative Proceedings, which partially acknowledged the appeal of the Professor of agricultural chemistry of that University. The professor raised two issues in the action. First, that she was ordered to teach biochemistry, a subject she herself did not deem to be a specialist in, while the subject which she specialized in, namely Agricultural Chemistry, was entrusted to a teacher with less preparation and having a lower academic title than she had. Second, the professor filed a lawsuit against the Department's decision to set up joint examinations, depriving her of the possibility to independently verify the knowledge of her students. The Spanish National Court-Chamber for Contentious-Administrative Proceedings considered assigning biochemistry to the Professor as lawful. At the same time, the Court found that Professor of agricultural chemistry had the right to examine his students. If this right

\footnotetext{
${ }^{6}$ The Constitutional Court of Spain found that the universities' right to autonomy referred to in Article 27(10) of the Constitution is a fundamental right, not merely an institutional guarantee. Cf. STC 26/1987, de 27 de febrero.
} 
is not abandoned, the department authorities should not entrust the examination to other persons. The decision of this court has been questioned before the Constitutional Court.

In this case, the principles according to which the Court settled the collision of principles were not clearly marked. It is difficult to determine from the content of the judgment whether the Constitutional Court used the test of proportionality to resolve the conflict. However, some elements can be noted. We know the goals of restricting the freedom of teaching. The Court indicated that the decision of the Faculty Council was motivated by the desire to obtain higher average student results and the proper functioning of teaching. The Court found the means taken by the Faculty as adequate. The Court noted that, in this case, we cannot say that the Department arbitrarily limited academic freedoms. The teacher who had been teaching Biochemistry was going on maternity leave, leaving the claimant the only member of the Department who had a knowledge and experience in this subject. So she was the most suitable teacher to replace the leaving teacher. The content of the judgment does not indicate that the Court investigated whether the means taken by the department restricted the freedom of teaching in the smallest degree and whether the social benefits of restricting the freedom to teach in this way outweighed its costs.

In the analyzed case, two issues important for academic freedom were raised. The first concerned whether the examination is part of the freedom of teaching or the autonomy of the university. The Court considered it to be part of the latter. Second, whether it was possible to order an academic teacher to teach a subject they are not specialized in instead of the subject they are specialized in. The Court decided that the teacher may be obliged by the Faculty Council to teach courses different than the ones they specialized. Nevertheless, such a decision should always be justified and necessary. The Court agreed in these particular circumstances for the institutional right such as university autonomy to prevail over individual rights, such as academic freedom. This phenomenon was accurately described by Álvarez González (2010, 7), who postulated that academic freedom does not deprive the academic institutions from deciding on organization of the education process. Therefore, academic freedom cannot be understood as giving a teacher a right to self-regulate their teaching in all aspects entirely and independently from the organizational criteria of the management of a university.

\section{Concluding remarks}

Some elements of academic freedom are understood similarly by the courts. First, academic freedom protects the individual from unjustified interference from public authority and/or university. Menand (1996) also points out that academic freedom protects academics from other academics. Second, university autonomy exists to protect academic freedom. Third, academic freedom may be limited in order to protect rights and freedoms of other people.

The freedom of scientific research in the assessment of constitutional courts is primarily freedom to choose subjects for research, choose their methodology, and publish their results. The three aspects of the freedom of scientific research are also indicated in the literature (see also: Feldman 1989, 507). Independence in the selection of didactic content and the used methods as well as the right to express scientific opinions are important aspects of the freedom of teaching in the assessment of constitutional courts.

The investigated cases prove that academic freedom can conflict with the individual rights, such as the right to respect private life, with institutional rights such as university autonomy, or the right of the religious community to self-determination. In collision with the right to respect 
private life and the right of the religious community to self-determination, it turns out to be a weak right. Obviously it does not mean that in the conflict with other fundamental rights not considered in this article, it could not turn out to be a strong right. Answering this question requires extending the research to other jurisdictions and analyzing subsequent conflicts of principles. Academic freedom is a strong right when it collides with the university's right to autonomy, which results mainly from the fact that the main purpose of the university's autonomy is the protection of academic freedom. Of course, one can argue whether the analysis of only five decisions of the courts is sufficient to state with certainty that a given fundamental right is weak, that is, it loses in the collision with other rights. However, the courts of all countries examined here adjudicate in a system with a doctrine of jurisprudence constante. In such a system, a line of authority emerges, the essence of which is that most courts dealing with a similar case decide it identically or similarly. Therefore, it can be expected with high probability for another collision of academic freedom with a given right, the court will rule consistently with previous verdicts.

My research also revealed that, when the courts decide the conflict between academic freedom and university autonomy, the latter is perceived as a distinct right but not another aspect of academic freedom.

Academic freedom is exposed to a proportionality analysis because the constitutional courts clearly prefer the limitation clause based on the protection of other individual rights. However, elements of the proportionality test were clearly identified only in three examined cases: German, Italian, and Polish. In these judgments, three criteria were decisive: the existence of a legitimate aim; the adoption of a less restrictive means test; and the use of a balancing exercise, or strict proportionality. The Italian, Polish, and Spanish cases prove that the lack of a legal definition or consent about the essence of academic freedom does not prevent the court from resolving a conflict.

Finally, the research indicates that the conflicts of principles, one of which is academic freedom, rarely take the form of a dispute in court. Consequently, there are not many cases which could be used by judges and scientists.

Supplementary Information The online version contains supplementary material available at https://doi.org/ 10.1007/s10734-021-00718-3.

Acknowledgements I am grateful to two anonymous referees for their detailed comments. Thanks are also due to Jeff McMahan (University of Oxford), Viriato Soromenho-Marques (University of Lisbon), David Benatar (University of Cape Town), Filipe Nobre Faria (Nova University of Lisbon), and other participants at the Conference on "The Status of Academic Freedom" (Nova University of Lisbon, September 10, 2019). I thank the constitutional courts in Belgium, Italy, Germany, and Portugal for the help in accessing the necessary information presented and referred in this paper.

Funding I thank the Polish National Research Council (NCN) for financial support (2016/23/D/HS5/00206).

Supplementary Information The online version contains supplementary material available at https://doi.org/ 10.1007/s10734-021-00718-3.

Open Access This article is licensed under a Creative Commons Attribution 4.0 International License, which permits use, sharing, adaptation, distribution and reproduction in any medium or format, as long as you give appropriate credit to the original author(s) and the source, provide a link to the Creative Commons licence, and indicate if changes were made. The images or other third party material in this article are included in the article's 
Creative Commons licence, unless indicated otherwise in a credit line to the material. If material is not included in the article's Creative Commons licence and your intended use is not permitted by statutory regulation or exceeds the permitted use, you will need to obtain permission directly from the copyright holder. To view a copy of this licence, visit http://creativecommons.org/licenses/by/4.0/.

Open Access This article is licensed under a Creative Commons Attribution 4.0 International License, which permits use, sharing, adaptation, distribution and reproduction in any medium or format, as long as you give appropriate credit to the original author(s) and the source, provide a link to the Creative Commons licence, and indicate if changes were made. The images or other third party material in this article are included in the article's Creative Commons licence, unless indicated otherwise in a credit line to the material. If material is not included in the article's Creative Commons licence and your intended use is not permitted by statutory regulation or exceeds the permitted use, you will need to obtain permission directly from the copyright holder. To view a copy of this licence, visit http://creativecommons.org/licenses/by/4.0/.

\section{References}

Act of 22 April (1998). on Higher Education Institutions and on Amendments and Supplements of Other Acts, accessed from: https://www.msmt.cz/uploads/odbor_30/TF/Legislativa_a_metodicke_pokyny/Novela_ 2016/Zakon_o_vysokych_skolach_AJ.pdf

Act of 3 July 2018. The Law on Higher Education and Science, accessed from: https://konstytucjadlanauki.gov. pl/content/uploads/2020/06/act-of-20-july-2018-the-law-on-higher-education-and-science.pdf

Alexy, R. (2000). On the structure of legal principles. Ratio Juris, 13(3), 294-304.

Alexy, R. (2002). A theory of constitutional rights, Oxford University Press.

Alexy, R. (2015). On constitutional rights to protection. Legisprudence, 3(1), 1-17.

Alexy, R. (2020). Non-positivistic concept of constitutional rights. International Journal for the Semiotics of Law, 33, 35-46.

Ali Nasir, M. (2018). Negative governmentality through fundamental rights: The far side of the European Convention on Human. European Law Journal, 24(4-5), 297-320.

Altbach, F. (2001). Academic freedom: International realities and challenges. Higher Education, 41, $205-219$.

Álvarez González, E. M. (2010). La libertad de cátedra y el profesorado universitario ante el espacio europeo de educación superior. Revista Juridíca de Investigación e Innovación Educativa, 2, 69-80.

Barak, A. (2012). Proportionality. Cambridge University Press.

Barendt, E. (2010). Academic freedom and the law. Hart Publishing.

Basic Law for the Federal Republic of Germany of 23 May (1949), accessed from: https://www.gesetze-iminternet.de/englisch_gg/englisch_gg.html\#p0014

Beiter, K. D., Karran, T., \& Appiagyei-Atua, K. (2016). Academic freedom and its protection in the law of European States: Measuring an international human right. European Journal of Comparative Law and Governance, 3(3), 254-345.

Brems, E., \& Lavrysen, L. (2015). Don't use a sledgehammer to crack a nut: Less restrictive means in the case law of the European Court of Human Rights. Human Rights Law Review, 15(1), 139-168.

Charter of Fundamental Rights and Freedoms of Czechia of 16 December 1992, accessed from: https://www.psp. cz/en/docs/laws/listina.html

Charter of Fundamental Rights of the European Union (2000) (C 364/01), accessed from: https://eur-lex.europa. eu/legal-content/EN/TXT/?uri=CELEX\%3A12012P\%2FTXT

Code de l'éducation (2020), accessed from: https://www.legifrance.gouv.fr/loda/article_lc/ LEGIARTI000006524458/2020-10-22

Cohen-Eliya, M., \& Porat, I. (2010). American Balancing and German Proportionality: The Historical Origins. International Journal of Constitutional Law, 8(2), 263-286.

Constitution of the Belgium 18317 February, accessed from: https://www.senate.be/doc/const_fr.html\#t2

Constitution of the France (1958) 4 October, accessed from: https://www.conseil-constitutionnel.fr/sites/default/ files/as/root/bank_mm/anglais/constiution_anglais_oct2009.pdf

Constitution of the Italian Republic (1947) 22 December, accessed from: http://www.jus.unitn.it/dsg/ pubblicazioni/costituzione/costituzione\%20genn2008eng.pdf

Constitution of the Portuguese Republic (1974) 25 April, accessed from: https://dre.pt/constitution-of-theportuguese-republic

Constitution of the Republic of Poland (1997) 2 April, accessed from: https://www.sejm.gov.pl/prawo/konst/ angielski/konl.htm 
Constitution of the Spain (1978) 31 October, accessed from: https:/www.senado.es/web/conocersenado/normas/ constitucion/detalleconstitucioncompleta/index.html\#preambulo

Constitutional Court in France (1993). Décision n ${ }^{\circ}$ 93-322 DC du 28 juillet, accessed from: https://www.conseilconstitutionnel.fr/decision/1993/93322DC.htm

Constitutional Court of Belgium (2005). Arrêt n 167 du 23 novembre, accessed from: https://www.etaamb.be/fr/ document n2005203249.html

Constitutional Court of Czechia (2008). 13. Března P1.ÚS 25/07, accessed from: http://nalus.usoud.cz/Search/ GetText.aspx?sz=P1-25-07

Constitutional Court of Czechia (2017). 13. září III.ÚS 3393/15, accessed from: https://www.usoud.cz/fileadmin/ user_upload/Tiskova_mluvci/Publikovane_nalezy/2017/III._US_3393_15_na_web_vc._disentu.pdf

Constitutional Court of Hungary (1994). 34/ (프. 24.) AB határozat, accessed from: http://jogszabalyfigyelo.hu/ index.php?id $=4259$ sxvyekraqpa $7 \mathrm{x} \&$ state $=20010514 \& \mathrm{menu}=\mathrm{view}$

Constitutional Court of Italy (1972). Sentenza n. 143 del 6 luglio, accessed from: https:/www.giurcost.org/ decisioni/1972/0143s-72.html

Constitutional Court of Italy (2017). Sentenza n. 42 del 21 febbraio 2017, accessed from: https://www. cortecostituzionale.it/actionSchedaPronuncia.do?anno $=2017$ \&numero $=42$

Constitutional Court of Poland (2000). Wyrok z 8 listopada r., sygn. SK 18/99, accessed from: http://isap.sejm. gov.pl/isap.nsf/download.xsp/WDU20001011091/T/D20001091TK.pdf

Constitutional Court of Poland (2006). Wyrok z dnia 7 lutego r., sygn. akt SK 45/04, accessed from: http://isap. sejm.gov.p1/isap.nsf/download.xsp/WDU20060250192/T/D20060192TK.pdf

Constitutional Court of Poland (2008). Wyrok z dnia 25 listopada r., sygn. akt K 5/08, accessed from: http:/isap. sejm.gov.pl/isap.nsf/download.xsp/WDU20082161380/T/D20081380TK.pdf

Constitutional Court of Poland (2012). Wyrok z dnia 12 kwietnia r., sygn. akt. K 30/10, accessed from: http:// isap.sejm.gov.pl/isap.nsf/download.xsp/WDU20120000431/T/D20120431TK.pdf

Constitutional Court of Spain (1981). STC 5 de 13 febrero, accessed from: https:/hj.tribunalconstitucional.es/es/ Resolucion/Show $/ 5$

Constitutional Court of Spain (1987). STC 26 de 27 de febrero, accessed from: http:/hj.tribunalconstitucional.es/ HJ/es-ES/Resolucion/Show/SENTENCIA/1987/26

Constitutional Court of Spain (1996). STC 179 de 12 de noviembre, accessed from: http://hj. tribunalconstitucional.es/es-ES/Resolucion/Show/3231

Constitutional Courts of Italy (1988). Sentenza n. 1017 del 26 ottobre, accessed from: https:/www.giurcost.org/ decisioni/1988/1017s-88.html

Contiades, X., \& Fotiadou, A. (2012). Social rights in the age of proportionality: Global economic crisis and constitutional litigation. International Journal of Constitutional Law, 10(3), 660-686.

Da Silva, V. A. (2011). Comparing the incommensurable: Constitutional principles, balancing and rational decision. Oxford Journal of Legal Studies, 31(2), 273-301.

Davies, M. (2015). Academic freedom: A lawyer's perspective. Higher Education, 70, 987-1002.

Decree defining higher education (2004) March 31 promoting its integration into the European space of higher education and refinancing the universities, accessed from: https:/www.gallilex.cfwb.be/document/pdf/ 28769_017.pdf

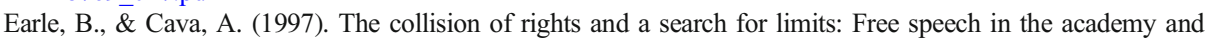 freedom from sexual harassment on campus. Berkeley Journal of Employment and Labor Law, 18(2), 282322.

Enders, J., de Boer, H., \& Weyer, E. (2013). Regulatory autonomy and performance: The reform of higher education re-visited. Higher Education, 65(1), 5-23.

Federal Constitutional Court of Germany (1973). Beschluss vom 29. Mai 1 BvR 424/71, 1 BvR 325/72, accessed from: https://dejure.org/dienste/vernetzung/rechtsprechung?Gericht=BVerfG\&Datum=29.05. 1973\&Aktenzeichen=1\%20BvR\%20424\%2F71

Federal Constitutional Court of Germany (2008) Beschluss vom 28. Oktober 1 BvR 462/06, accessed from: https:/www.bundesverfassungsgericht.de/SharedDocs/Downloads/DE/2008/10/rs20081028_1bvr046206. pdf? _ blob=publicationFile $\& v=1$

Federal Constitutional Court of Germany (2010). Beschluss vom 20. Juli BvR 748/06, accessed from: https:// www.bundesverfassungsgericht.de/SharedDocs/Entscheidungen/DE/2010/07/rs20100720_1bvr074806. html

Feldman, D. (1989). The nature of legal scholarship. Modern Law Review, 52(4), 498-517.

Feteris, E. T. (2008). The rational reconstruction of weighing and balancing on the basis of teleologicalevaluative considerations in the justification of judicial decisions. Ratio Juris, 21(4), 481-495.

Framework law on higher education (1999). from January 19th, accessed from: https://www.bgbl.de/xaver/bgbl/ start.xav\#_bgbl_\%2F\%2F*\%5B\%40attr_id\%3D\%27bgb1199s0018.pdf\%27\%5D_1614191584646 
Fundamental Law of Hungary 2011 April 25, accessed from: https:/hunconcourt.hu/uploads/sites/3/2021/01/ thefundamentallawofhungary 20201223 fin.pdf

Gibbs, A. (2016). Academic freedom in international higher education: Right or responsibility? Ethics and Education, 11(2), 175-185.

Grimm, D. (2015). The role of fundamental rights after sixty-five years of constitutional jurisprudence in Germany. International Journal of Constitutional Law, 13(1), 9-29.

Habermas, J. (1996). Between facts and norms, trans. W. Reh, Cambridge.

Harbo, T.-I. (2010). The function of the proportionality principle in EU Law. European Law Journal, 16(2), 158-185.

Jackson, V. C. (2015). Constitutional law in an age of proportionality. Yale Law Journal, 124(8), 3094-3196.

Karran, T. (2009a). Academic freedom in Europe: Time for a Magna Charta? Higher Education Policy, 22, 163189.

Karran, T. (2009b). Academic freedom in Europe: Reviewing Unesco's recommendation. British Journal of Educational Studies, 57(2), 191-215.

Karran, T., Beiter, K., \& Appiagyei-Atua, K. (2017). Measuring academic freedom in Europe: A criterion referenced approach. Policy Reviews in Higher Education, 11(2), 209-239.

Khosla, M. (2010). Proportionality: An assault on human rights?: A reply. International Journal of Constitutional Law, 8(2), 298-306.

Klatt, M., \& Meister, M. (2012). Proportionality - A benefit to human rights? Remarks on the $\mathrm{I} \cdot \mathrm{CON}$ Controversy. International Journal of Constitutional Law, 10(3), 687-708.

Kumm, M. (2007). Political liberalism and the structures of rights: On the place and limits of the proportionality requirement. In G. Pavlakos (Ed.), Law, Rights, Discourse. The Legal Philosophy of Robert Alexy (131-166). Hart Publishing.

La Torre, M. (2018). Human rights: Existential, not metaphysical. Ratio Juris, 31(2), 184-195.

Legge (2010) 30 dicembre 240, Norme in materia di organizzazione delle università, di personale accademico e reclutamento, nonce delega al Governo per incentivare la qualità e l'efficienza del sistema universitario, accessed from: https://www.camera.it/parlam/leggi/102401.htm

Ley Orgánica (2001). 6 de 21 de diciembre, de Universidades, accessed from https://www.boe.es/buscar/pdf/ 2001/BOE-A-2001-24515-consolidado.pdf

Loi du (1931). 31 mars portant fixation du budget général de l'exercice 1931-1932, accessed from: http://lexpol. cloud.pf/document.php?document=306355\&deb=391\&fin=392\&titre=TG9pIGR1IDMxLzAzLzE5MzE=

Matejkovic, J. E., \& Redle, D. A. (2006). Proceed at your own risk: The balance between academic freedom and sexual harassment. Brighman Young University Education and Law Journal, 1, 295-322.

Menand, L. (1996). The limits of academic freedom. In L. Menand (Ed.), The Future of Academic Freedom (pp. 3-20). University of Chicago Press.

Mimler, M. D. (2015). The public interest and the construction of exceptions to patentee's rights - A comparative study of UK and German law. University of London.

Möller, K. (2012). The global model of constitutional rights. Oxford University Press.

Novak, M. (2010). Three models of balancing (in constitutional review). Ratio Juris, 23(1), 101-112.

Popelier, P., \& van de Heyning, C. (2013). Procedural rationality: Giving teeth to the proportionality analysis. European Constitutional Law Review, 9(2), 230-262.

Poscher, R. (2020). Resuscitation of a phantom? On Robert Alexy's latest attempt to save his concept of principle. Ratio Juris, 33(2), 134-149.

Ramshaw, A. (2019). The case for replicable structured full proportionality analysis in all cases concerning fundamental rights. Legal Studies, 39(1), 120-142.

Rao, N. (2008). On the use and abuse of dignity in constitutional law. Columbia Journal of European Law, 14(2), 201-256.

Rena, K., \& Li, J. (2013). Academic freedom and university autonomy: A higher education policy perspective. Higher Education Policy, 26(4), 507-522.

Rittberger, B., \& Richardson, J. (2019). What happens when we do not defend academic freedom. Journal of European Public Policy, 26(3), 324.

Rivers, J. (2014). The presumption of proportionality. Modern Law Revue, 77(3), 409-433.

Stacey, R. (2019). The magnetism of moral reasoning and the principle of proportionality in comparative constitutional adjudication. The American Journal of Comparative Law, 67(2), 435-475.

Stachowiak-Kudła, M. (2020). Transnational judicial dialogue in case law related to academic freedom. In A. Kłos, J. Misiuna, M. Pachocka, \& A. Szczerba-Zawada (Eds.), European Union and its values: Freedom, solidarity and democracy (Vol. 1, pp. 17-29). CEDEWU.

Starck, C. (2006). Freedom of scientific research and its restrictions in German constitutional law. Israel Law Review, 39(2), 110-126. 
Thorens, J. (2006). Liberties, freedom and autonomy: A few reflections on academia's estate. Higher Education Policy, 19(1), 87-110.

Tremblay, L. B. (2014). An egalitarian defense of proportionality-based balancing. International Journal of Constitutional Law, 12(4), 864-890.

Tsakyrakis, S. (2009). Proportionality: An assault on human rights? International Journal of Constitutional Law, 7(3), 468-493.

UNESCO (1997). Recommendation concerning the status of higher-education teaching personnel, 11 November accessed from: https://unesdoc.unesco.org/ark:/48223/pf0000113234.page $=2$

Urbina, F. J. (2005). Incommensurability and balancing. Oxford Journal of Legal Studies, 35(3), 575-605.

Webber, G. (2009). The negotiable constitution: On the limitation of rights. Cambridge University Press.

Weinrib, J. (2017). When Trumps clash: Dworkin and the doctrine of proportionality. Ratio Juris, 30(3), 341352 .

Publisher's note Springer Nature remains neutral with regard to jurisdictional claims in published maps and institutional affiliations. 